\title{
Arsenic trioxide-induced cytotoxicity in small cell lung cancer via altered redox homeostasis and mitochondrial integrity
}

\author{
CHUN-YAN ZHENG, SZE-KWAN LAM, YUAN-YUAN LI and JAMES CHUNG-MAN HO \\ Division of Respiratory Medicine, Department of Medicine, The University of Hong Kong, \\ Queen Mary Hospital, Hong Kong, SAR, P.R. China
}

Received September 20, 2014; Accepted November 4, 2014

DOI: $10.3892 /$ ijo.2015.2826

\begin{abstract}
Arsenic trioxide (ATO) has demonstrated anticancer activity in different malignancies, especially acute promyelocytic leukemia, with a wide array of putative mechanisms. In this study, we aimed to elucidate the activity and mechanisms of ATO in small cell lung cancer (SCLC). A panel of SCLC cell lines (H841, DMS79, H526, H69 and H187) was employed to demonstrate the activity of ATO. Cell viability, apoptosis and mitochondrial membrane depolarization were assessed. Western blotting was performed to determine the alteration of pro-apoptotic and anti-apoptotic mediators. Reactive oxygen species (ROS) (hydrogen peroxide and superoxide) and intracellular glutathione (GSH) were measured. Antioxidants, N-acetyl-L-cysteine (NAC) and butylated hydroxyanisole (BHA), were applied to restore GSH content and reduce production of ROS. All SCLC cell lines were relatively sensitive to ATO with $\mathrm{IC}_{50}$ values below $10 \mu \mathrm{M}$. ATO induced cell death mainly through apoptosis in H841 cells in a dose-dependent manner. Hydrogen peroxide was the major ROS in SCLC cells induced by ATO. Along with GSH depletion and $\mathrm{Bcl}-2$ downregulation, mitochondrial membrane permeabilization was enhanced, followed by release of AIF and SMAC from mitochondria to initiate different cell death pathways. NAC reversed cell death and molecular changes induced by ATO via restoring GSH and reducing ROS content. BHA inhibited hydrogen peroxide production completely and partially restored GSH content accounting for partial reversal of cell inhibition and mitochondrial dysfunction. Nonetheless,
\end{abstract}

Correspondence to: Dr James C.-M. Ho, Department of Medicine, The University of Hong Kong, Queen Mary Hospital, Pokfulam, Hong Kong, SAR, P.R. China

E-mail: jhocm@hku.hk

Abbreviations: ATO, arsenic trioxide; BHA, butylated hydroxyanisole; GSH, glutathione; NAC, N-acetyl-L-cysteine; SMAC/ DIABLO, second mitochondria-derived activator of caspases; Trx1, thioredoxin 1; XIAP, X-linked inhibitor of apoptosis protein

Key words: arsenic trioxide, apoptosis, mitochondrial membrane depolarization, glutathione, hydrogen peroxide, thioredoxin 1
ATO reduced both reduced and oxidized form of thioredoxin 1 (Trx1) with no effect on Trx1 redox potential. ATO led to cell death in SCLC mainly through mitochondrial dysfunction, resulting from altered cellular redox homeostasis, namely, hydrogen peroxide generation, GSH depletion and Trx1 downregulation.

\section{Introduction}

SCLC, accounting for $15-20 \%$ of newly diagnosed lung cancer, is an extremely aggressive malignancy with early metastasis and poor prognosis. Despite a prompt response to chemotherapy, relapses occur in the majority of patients with SCLC. Therefore the development of an alternative therapy against SCLC becomes imperative (1).

ATO has been proven to be an effective therapeutic agent in acute promyelocytic leukemia (APL) with high complete remission rate and prolonged survival $(2,3)$. ATO can induce apoptosis through PML-RAR $\alpha$-independent pathways in APL or other cancer cells via p53 activation (4,5), Bcl-2 downregulation $(6,7)$, mitochondrial membrane depolarization and cytochrome $c$ release (8-10), depletion of intracellular reduced glutathione (GSH) content and elevation of reactive oxygen species $(11,12)$. More recently, the application of ATO in lung cancer treatment has been explored in preclinical models, mainly in non-small cell lung cancer (NSCLC). ATO induces growth inhibition and apoptosis in NSCLC cells through G2/M cell cycle arrest $(13,14)$, Bcl-2 downregulation and GSH depletion (15). Recently, downregulation of thymidylate synthase and E2F1 were observed in lung adenocarcinoma $(16,17)$ and mesothelioma (18). Synergistic effects have been observed when combining ATO with cisplatin (19), buthionine sulfoximine (BSO) (15), suberoylanilide hydroxamic acid (20), and sulindac (21). The effect of ATO in SCLC is less reported. In a panel of lung cancer cell lines, ATO is highly cytotoxic to SCLC preferentially mediated through necrosis rather than apoptosis (22).

Biologically, ATO is known to bind to proteins with sulfhydryl (-SH) groups (23). It targets GSH which is a thiol molecule involved in detoxification of arsenicals $(11,24)$. Evidently, loss of GSH and its cytotoxic effect is not directly caused by damage of GSH-related enzymes (glutathione peroxidase, glutathione reductase and glutathione transferase) (25). Nonetheless, thioredoxin ( $\operatorname{Tr} x)$ system serves as a key 
antioxidant target of ATO in breast cancer cells (26). Trx system, composed of thioredoxin reductase (TrxR), Trx and $\mathrm{NADPH}$, plays an important role in maintaining somatic redox homeostasis. Moreover, TrxR and Trx are overexpressed in many cancers (27-29), which take part in redox regulation of transcription factors (30). Therefore, Trx system has become a new target in cancer therapy (31).

In the present study, we aimed to elucidate the mechanisms of ATO in SCLC using a cell line model, which may provide a scientific base for future application of ATO in treatment of SCLC.

\section{Materials and methods}

Chemicals and reagents. ATO, N-acetyl-L-cystine (NAC), buthionine sulphoximine (BSO) and butylated hydroxyanisole (BHA) were obtained from Sigma-Aldrich (St. Louis, MO, USA). Apoptosis inducing factor (AIF), Bcl-2, cleaved caspase-3, cytochrome $c$, PARP, SMAC, thioredoxin and XIAP antibodies were purchased from Cell Signaling Technology (Danvers, MA, USA).

Cell lines and culture. Five SCLC cell lines (H187, DMS79, H526, H69 and H841) were obtained from the American Type Culture Collection (Manassas, VA, USA). H187, DMS79, H526 and H69 cells were cultured in RPMI-1640 medium (Gibco ${ }^{\circledR}$, Life Technologies, Carlsbad, CA, USA) supplemented with $10 \%$ fetal bovine serum (FBS, Gibco), while H841 cells were grown in HETIS medium supplemented with 5\% FBS. Cells were incubated in $37^{\circ} \mathrm{C}$ with a humidified atmosphere of $5 \% \mathrm{CO}_{2}$.

Cell proliferation assay. The cytotoxicity of ATO in SCLC cell lines was measured using 3-(4,5-dimethyl-thiazol-2-yl)2,5-diphenyl-tetrazolium bromide (MTT) assay (ATCC) as previously performed (32).

Annexin V-phycoerythrin (PE)/7-aminoactinomycin D $(A A D)$ staining. Apoptosis was determined by PE-conjugated Annexin V/7-AAD kit (BD Biosciences, CA, USA). Briefly, treated cells were collected, washed and re-suspended in binding buffer. Cells were stained for $15 \mathrm{~min}$ at room temperature with PE-Annexin V $(\mathrm{Ex} / \mathrm{Em}=488 / 578 \mathrm{~nm}) / 7-\mathrm{AAD}$ $(\mathrm{Ex} / \mathrm{Em}=546 / 647 \mathrm{~nm})$, then read-out by Cytomics FC 500 analyzer with FL2/FL4 channels (Beckman Coulter, CA, USA). The cell populations in $\mathrm{PE}^{+} / 7-\mathrm{AAD}^{-}$and $\mathrm{PE}^{+} / 7-\mathrm{AAD}^{+}$ quadrants were calculated.

Measurement of mitochondrial membrane depolarization $(M M D)$. Briefly, cells after treatment were collected, washed, and stained with $\mathrm{JC}-1(5 \mu \mathrm{g} / \mathrm{ml})$ at $37^{\circ} \mathrm{C}$ for $15 \mathrm{~min}$ before reading with FL1/FL2 channels of Cytomics FC 500 analyzer.

Detection of glutathione (GSH) and reactive oxygen species (ROS). Cellular GSH level was measured by using 5-chloromethylfluorescein diacetate $(\mathrm{CMFDA}, \mathrm{Ex} / \mathrm{Em}=522 / 595 \mathrm{~nm}$, Invitrogen, CA, USA) fluorescence as described previously (33). After treatment, cells were washed and incubated for 30 min at $37^{\circ} \mathrm{C}$ with $5 \mu \mathrm{M}$ CMFDA in FBS-free medium, followed by incubation for $40 \mathrm{~min}$ at $37^{\circ} \mathrm{C}$ with complete medium. CMF fluorescence intensity was determined using a Cytomics FC500 flow cytometer. Hydrogen peroxide $\left(\mathrm{H}_{2} \mathrm{O}_{2}\right)$ and superoxide were measured by $2^{\prime}, 7^{\prime}$-dichlorodihydrofluorescein diacetate $\left(\mathrm{H}_{2} \mathrm{DCFDA}, \mathrm{Ex} / \mathrm{Em}=500 / 520 \mathrm{~nm}\right)$ and dihydroethidium $(\mathrm{DHE}, \mathrm{Ex} / \mathrm{Em}=518 / 605 \mathrm{~nm})($ Invitrogen $)$ staining, respectively. Treated cells were washed and incubated for $20 \mathrm{~min}$ at $37^{\circ} \mathrm{C}$ with $1 \mu \mathrm{M}$ of $\mathrm{H}_{2}$ DCFDA or $1 \mu \mathrm{M}$ DHE in FBS-free medium following flow cytometry.

Immunofluorescence. Oxidative DNA damage was assessed using 8-hydroxy-2-deoxyguanosine (8-OHdG) immunofluorescence. Cells were seeded on slides before treatment. Slides were washed and blocked for 60 min with $10 \%$ normal goat serum in PBS, followed by incubation at $4^{\circ} \mathrm{C}$ overnight with monoclonal anti-8-OHdG antibody (Santa Cruz Biotechnology, Inc., Santa Cruz, CA, USA). The slides were then incubated for $2 \mathrm{~h}$ with FITC-conjugated goat anti-mouse IgG (Santa Cruz Biotechnology, Ex $/ \mathrm{Em}=500 / 520 \mathrm{~nm}$ ), coverslipped with UltraCruz ${ }^{\mathrm{TM}}$ Mounting Medium (Santa Cruz Biotechnology) and observed with Eclipse E-800 (Nikon, Tokyo, Japan). DAPI (Santa Cruz Biotechnology) staining was used to visualize the nucleus.

Western blotting. Total protein was extracted with RIPA buffer (PBS, $1 \%$ Nonidet-P-40, 0.1\% deoxycholate, $0.1 \%$ sodium dodecyl sulfate) containing protease inhibitors. Nuclear protein and mitochondrial protein were collected with NE-PER Nuclear and Cytoplasmic Extraction kit and Mitochondria Isolation kit respectively (Pierce Biotech, Rockford, IL, USA) as described by the manufacturer. Proteins $(40 \mu \mathrm{g})$ were separated in sodium dodecyl sulfate-polyacrylamide gel electrophoresis (SDS-PAGE), transferred to nitrocellulose membrane (GE Healthcare, Buckinghamshire, UK), immunoblotted with corresponding primary and secondary antibodies, and detected using ECL detection kit (GE Healthcare). Image analysis was carried out with ImageJ (Research Services Branch, National Institute of Mental Health, Bethesda, MD, USA).

DNA fragmentation assay. Cellular DNA was extracted with standard DNA phenol/chloroform extraction method (34). DNA (0.1 $\mu \mathrm{g} / \mathrm{sample})$ was separated in $1.5 \%$ agarose gel and bands were visualized on a UV transilluminator at $302 \mathrm{~nm}$.

Redox western blot analysis. Redox forms of Trx 1 were separated as previously described $(26,35)$. Trx 1 was carboxymethylated in guanidine-Tris solution $(6 \mathrm{M}$ guanidine- $\mathrm{HCl}$, $50 \mathrm{mM}$ Tris, $1 \mathrm{mM}$ EDTA, $30 \mathrm{mM}$ iodoacetic acid) at $\mathrm{pH}$ 7.5. After incubation at $37^{\circ} \mathrm{C}$ for $30 \mathrm{~min}$, proteins were desalted and concentrated using centrifugal filter device (Millipore, Billerica, MA, USA). Proteins were separated with native gel and western blotting was performed. Redox potential was calculated with Nernst equation: Eh, $\operatorname{Trx} 1=240 \mathrm{mV}+30 \times \ln$ (ratio of $\operatorname{Tr} \times 1^{0 \mathrm{x}}$ and $\left.\operatorname{Tr} \times 1^{\mathrm{Red}}\right)$ (36).

Statistical analysis. Data were presented as mean \pm standard deviation (SD), with between-group differences analyzed by two-tailed Student's t-test. A p-value $<0.05$ was considered statistically significant. Linear regression was used to calculate $\mathrm{IC}_{50}$ values. All statistical analyses were performed using Prism 5 (GraphPad Software, La Jolla, CA, USA). 
A

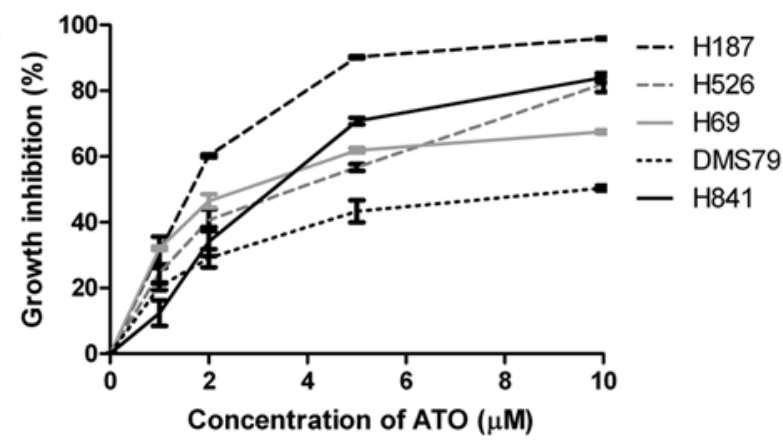

B
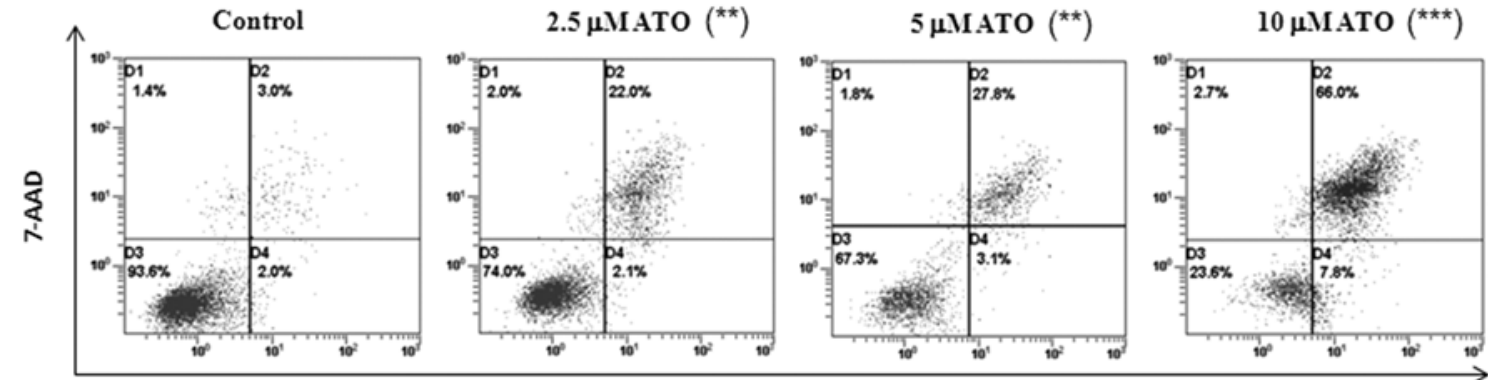

$\mathrm{C}$

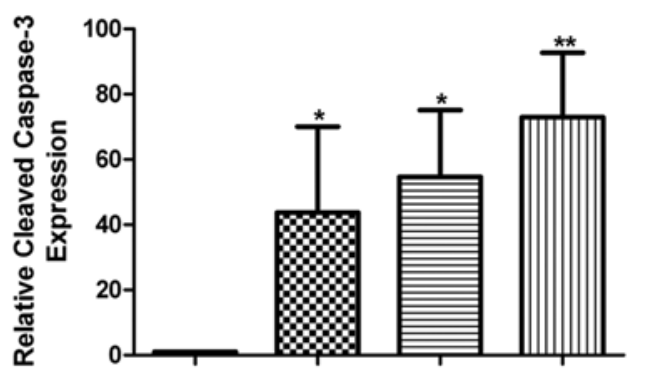

PE-Annexin V
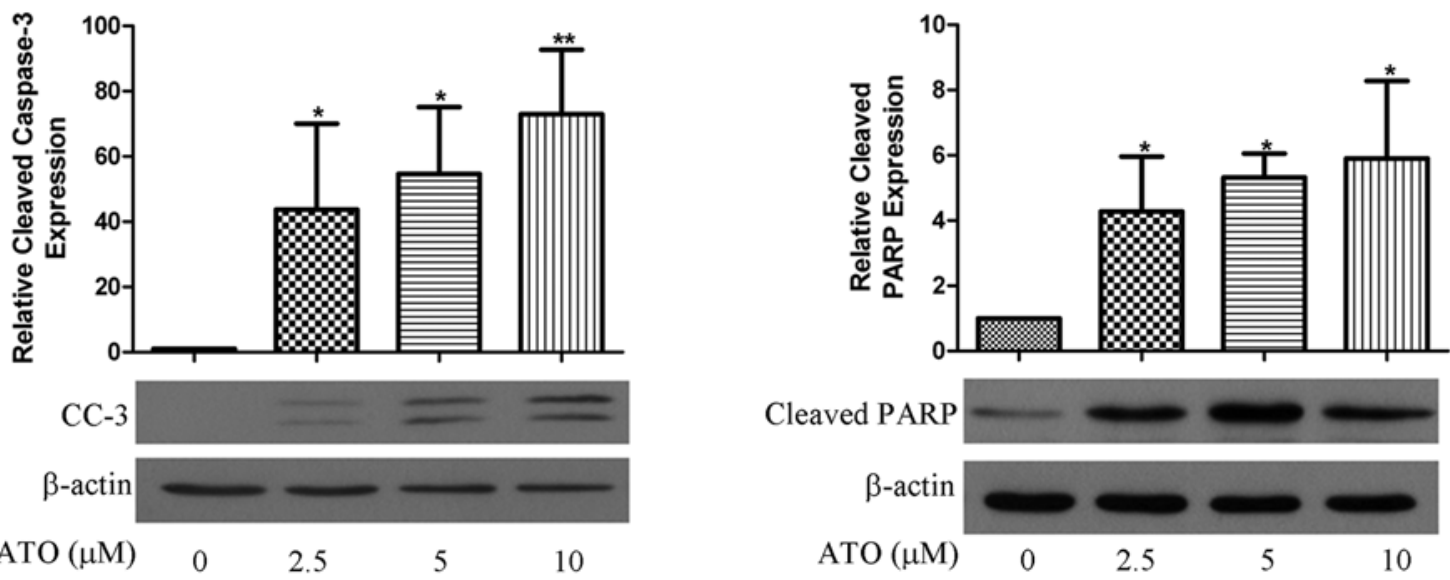

Figure 1. Cytotoxicity of ATO in SCLC cell lines. (A) Dose-dependent growth inhibition in five SCLC cell lines (H187, H526, H69, DMS79 and H841) with ATO treatment. (B) Dose-dependent increase in apoptotic cell death, (C) cleaved caspase-3 and cleaved PARP with ATO treatment in H841 cells. Statistical significance $\left({ }^{*} \mathrm{p}<0.05 ;{ }^{* *} \mathrm{p}<0.01\right.$ and $\left.{ }^{* * *} \mathrm{p}<0.001\right)$ indicates comparison with control.

\section{Results}

Cell growth inhibition and apoptosis induced by ATO. Five SCLC cell lines were incubated for $48 \mathrm{~h}$ with different concentrations of ATO. Cell proliferation was suppressed in a dose-dependent manner with $\mathrm{IC}_{50}$ values in clinically reachable levels (Fig. 1A). H841 cell line was chosen due to its adherent property for apoptotic assay. ATO induced dosedependent apoptosis (Fig. 1B) in H841 cells accompanied by increased cleaved caspase-3 and PARP (Fig. 1C).

ATO-induced MMD, GSH depletion and ROS elevation. ATO prompted a dose-dependent shift from red to green fluorescence that indicated MMD in H841 cells (Fig. 2A). This was associated with downregulation of Bcl-2 and XIAP as well as release of AIF and SMAC to cytosol (Fig. 2B). Low concentration of ATO $(2.5 \mu \mathrm{M})$ reduced $60 \%$ of GSH content (Fig. $2 \mathrm{C}$ ) and increased $\mathrm{H}_{2} \mathrm{O}_{2}$ by $>1.5$-fold compared with control $\mathrm{H} 841$ cells $(30500 \pm 6150$ vs $13522 \pm 3146)$ (Fig. 2D). Nonetheless, superoxide content remained unchanged except at the highest concentration $(10 \mu \mathrm{M})$ of ATO treatment (Fig. 2D).

ATO induced oxidative DNA damage and fragmentation. Treatment with ATO $(5 \mu \mathrm{M})$ resulted in stronger FITC fluorescence (green) than in the control group, in keeping with increased 8-OHdG content in H841 cells upon exposure to ATO (Fig. 3A). This is associated with appearance of lower molecular weight DNA fragments with ATO treatment (Fig. 3B).

Changes in MAPKs expression during ATO treatment. Elevation of p-Erk1/2 was detected after 30 min of ATO treatment and it was sustained for $\geq 48 \mathrm{~h}$ (Fig. 4A) while p-P38 and p-JNK were unaltered (data not shown). Nonetheless, application of specific p-Erk1/2 inhibitor (PD98059) $(20 \mu \mathrm{M})$ decreased p-Erk1/2 

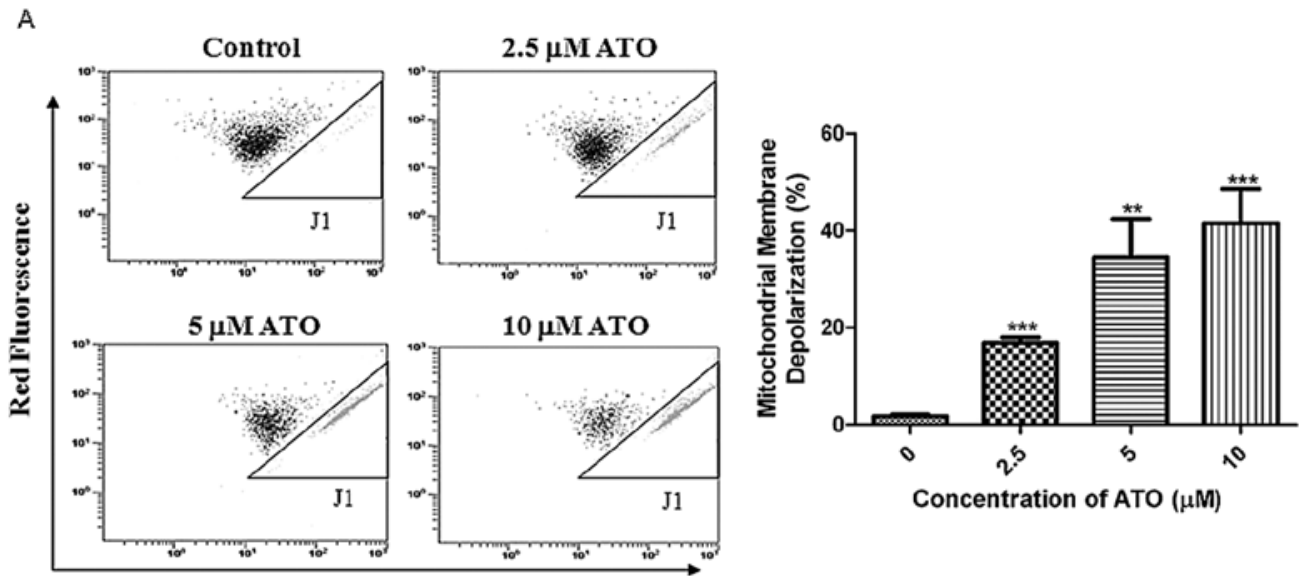

Green Fluorescence

B

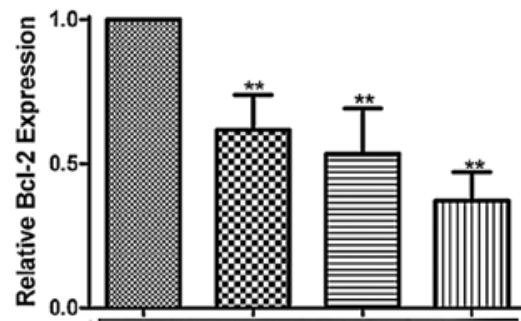

Bcl-2

$\beta$-actin

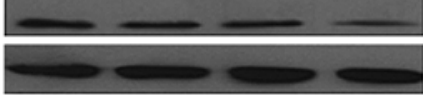

ATO $(\mu \mathrm{M}) \quad 0 \quad 2.5 \quad 5 \quad 10$

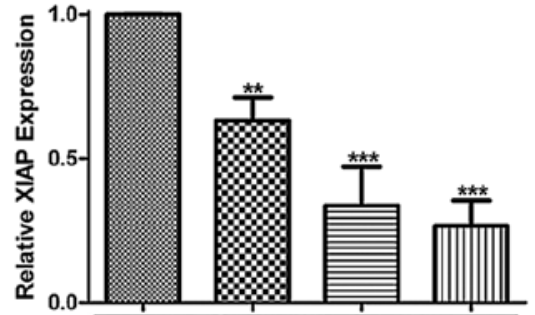

XIAP

$\beta$-actin

$\operatorname{ATO}(\mu \mathrm{M})$
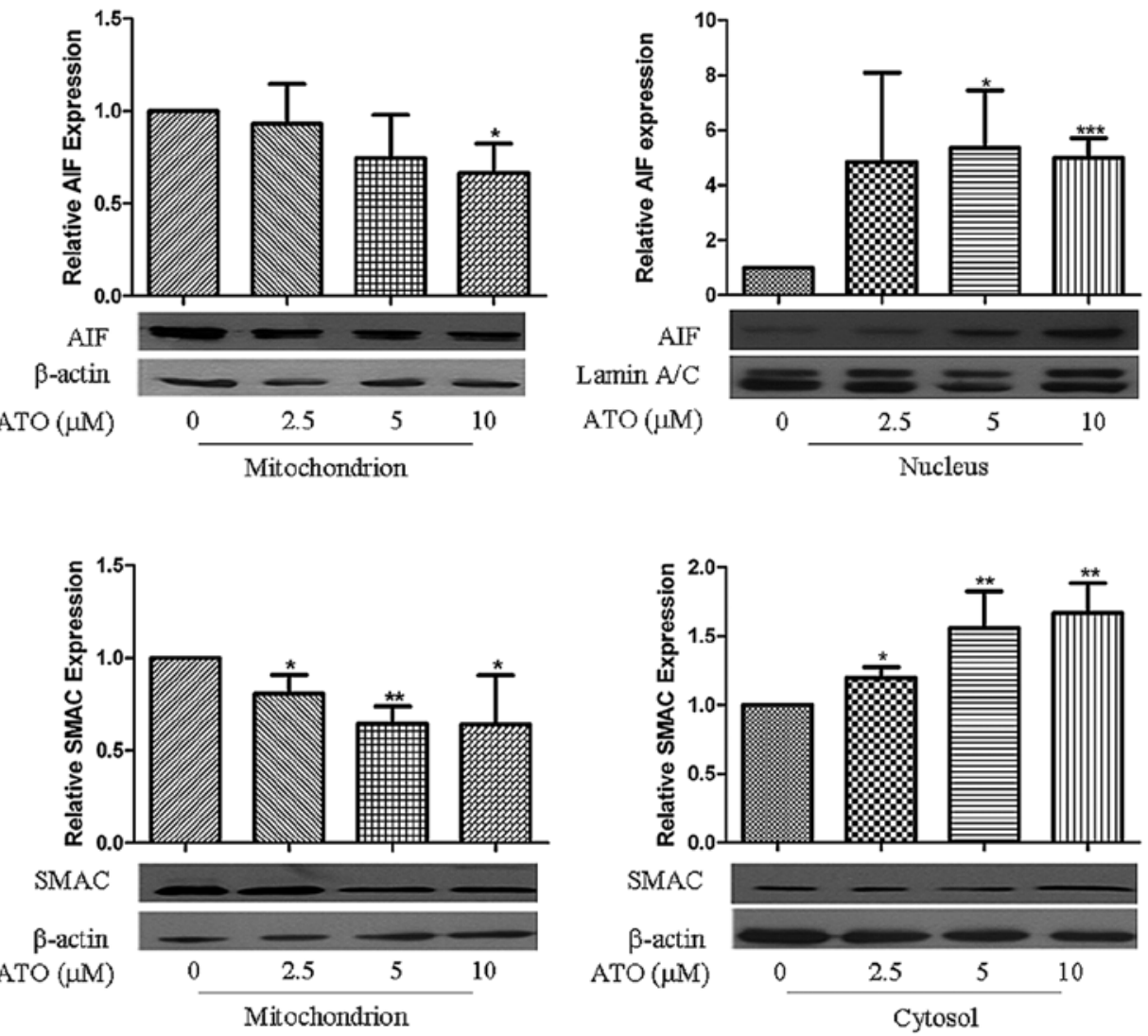

Figure 2. Effect of ATO on mitochondrial membrane permeability, apoptotic mediators or inhibitors as well as GSH depletion and $\mathrm{H}_{2} \mathrm{O}_{2}$ accumulation (A) Increased mitochondrial membrane depolarization (MMD) with ATO treatment as indicated by JC-1 staining. $\mathrm{J}_{1}$ represents the proportion of the cells with MMD. (B) Downregulation of apoptotic inhibitors (Bcl-2 and XIAP) with ATO treatment, associated with translocation of AIF and Smac from mitochondria to nucleus and cytosol respectively. 
C

Control

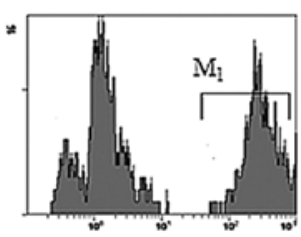

5 UM $\mathrm{MTO}$

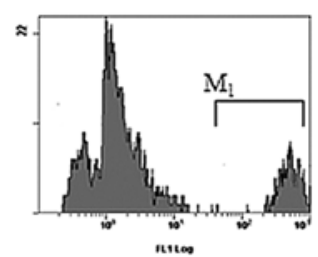

nitos
$2.5 \mu \mathrm{MATO}$

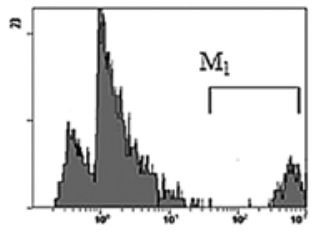

10 UMATO

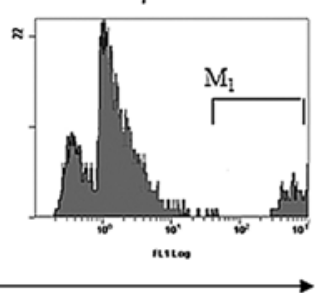

CMF Fluorescence

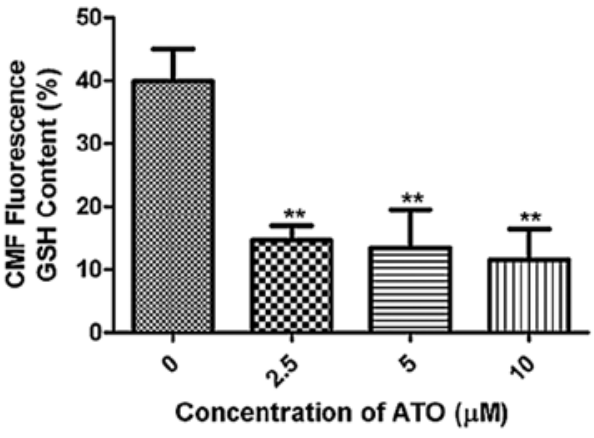

D

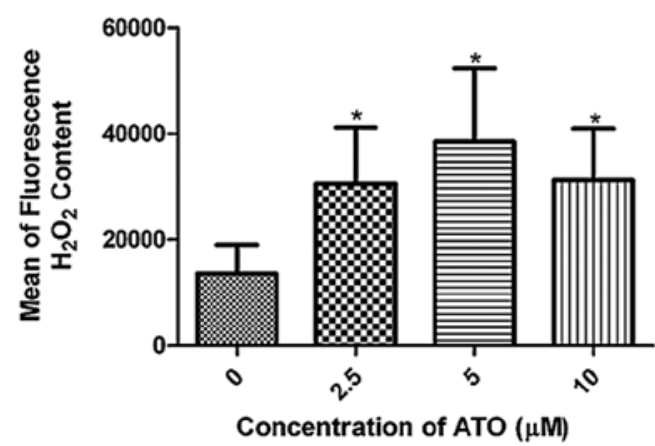

Figure 2. Continued. (C) ATO depleted GSH at $2.5 \mu \mathrm{M}$, with similar degree of suppression up to $10 \mu \mathrm{M}$. $\mathrm{M}_{1}$ represents the GSH content. (D) ATO significantly increased $\mathrm{H}_{2} \mathrm{O}_{2}$ at 2.5-10 $\mu \mathrm{M}$, while superoxide was significantly raised only at the highest concentration of ATO at $10 \mu \mathrm{M}$. Statistical significance ("p $<0.05$; ${ }^{* *} \mathrm{p}<0.01$ and $\left.{ }^{* * * *} \mathrm{p}<0.001\right)$ indicates comparison with control.

A

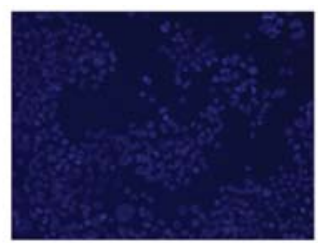

DAPI

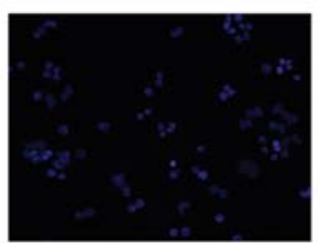

DAPI

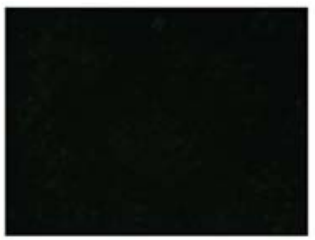

FITC-8-OHdG

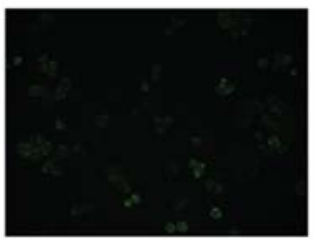

FITC-8-OHdG

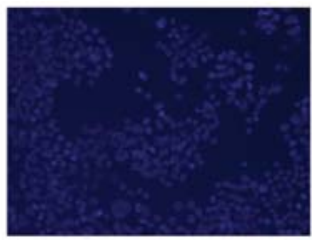

Control

Merged

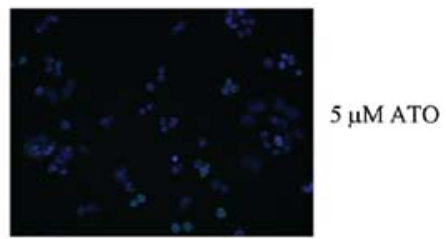

Merged

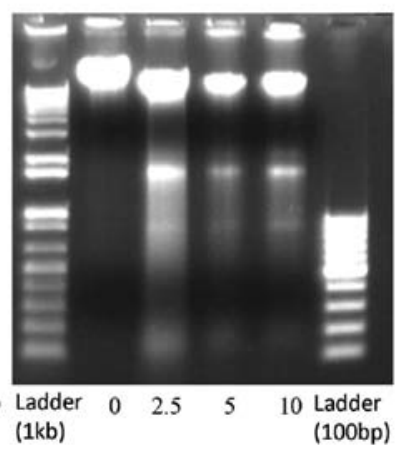

Figure 3. ATO caused DNA damage in $\mathrm{H} 841$ cell line. (A) The degree of oxidative DNA damage, as indicated by FITC-8-OHdG staining, was evident with ATO treatment $(5 \mu \mathrm{M})$ compared with control. (B) DNA fragmentation was noted with ATO treatment at different concentrations. 
A

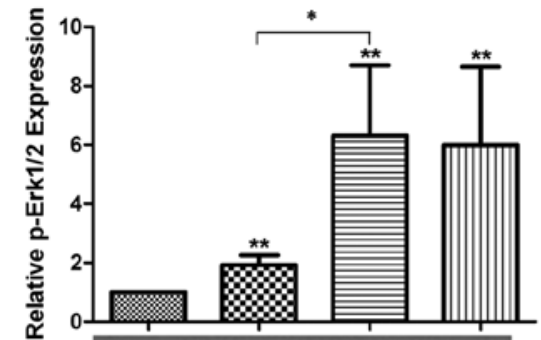

p-Erk1/2

Erk1/2

$\beta$-actin

$\operatorname{ATO}(\mu \mathrm{M})$

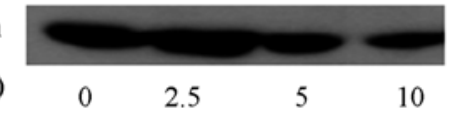

B

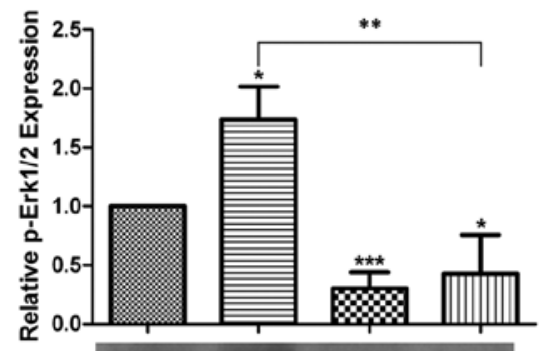

p-Erk1/2

Erk1/2
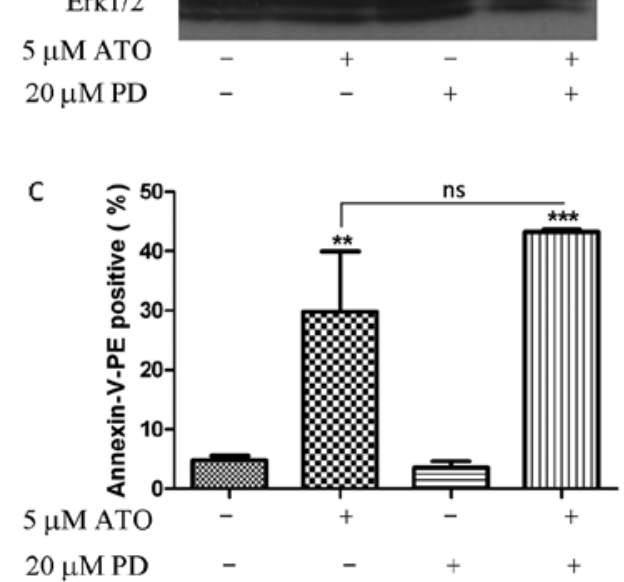

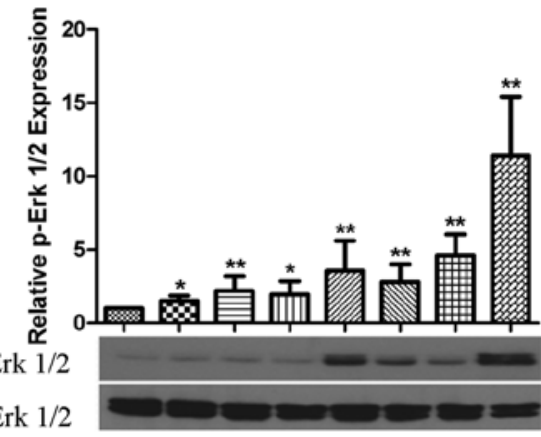

$\begin{array}{llllllll}0 & 0.5 & 1 & 2 & 6 & 12 & 24 & 48\end{array}$

Time of incubation with $5 \mu \mathrm{M}$ ATO (hr)

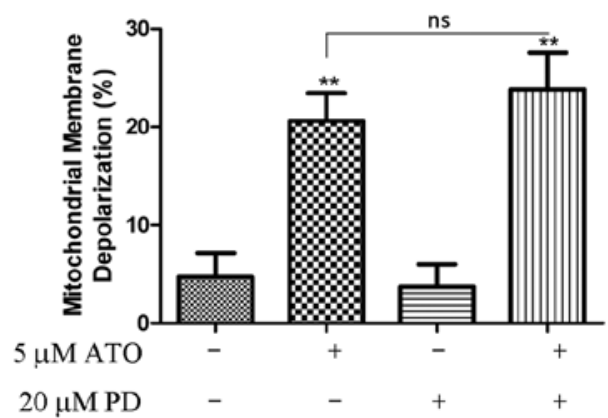

Figure 4. Upregulation of p-Erk1/2 with ATO in H841 cells had no cytotoxic effect. (A) Dose- and time-dependent induction of p-Erk1/2 upon ATO treatment. (B) PD-98059 $(20 \mu \mathrm{M})$ (Erk inhibitor) effectively suppressed ATO-induced pErk1/2, without alleviating effect on mitochondrial membrane depolarization and apoptosis initiated by ATO. Statistical significance $\left({ }^{*} \mathrm{p}<0.05 ;{ }^{* *} \mathrm{p}<0.01\right.$ and ${ }^{* * *} \mathrm{p}<0.001 ; \mathrm{ns}$, not significant) indicates comparison with control.

expression induced by ATO (Fig. 4B) but did not reverse ATO-induced cell death and MMD (Fig. 4C).

Effects of antioxidants on cell death induced by ATO. NAC, a cysteine donor in GSH synthesis, was used to determine the role of GSH and ROS in ATO-induced cell death in H841 cells. NAC $(10 \mathrm{mM})$ was shown to effectively restore GSH content and reduce $\mathrm{H}_{2} \mathrm{O}_{2}$ after ATO exposure (Fig. 5A). This was associated with reversal of apoptotic cell death $(39.6 \pm 5.3$ vs. $5.3 \pm 1.2 \%$ for ATO vs ATO + NAC) and MMD (34.5 \pm 4.5 vs. $5.6 \pm 0.4 \%$ for ATO vs. ATO + NAC) (Fig. $5 \mathrm{~B}$ ). In addition, NAC reversed the alterations in apoptosis-related proteins induced by ATO (Bcl-2, XIAP, cleaved caspase-3 and cleaved
PARP) (Fig. 5C). On the other hand, a different antioxidant BHA suppressed $\mathrm{H}_{2} \mathrm{O}_{2}$ induced by ATO but failed to restore GSH content. Consequently, BHA only partially reversed apoptosis and MMD induced by ATO (Fig. 5D).

$B S O$ potentiated cytotoxic effect of ATO by further disturbing the redox status. BSO, an inhibitor of $\gamma$-glutamylcysteine synthetase, was used as a GSH inhibitor. BSO potentiated the cytotoxic effect of ATO in H841 cells, as shown by increased apoptotic death ( $\mathrm{PE}^{+}$by flow cytometry in 17 vs. $44 \%$ : ATO vs. ATO + BSO), enhanced MMD (17 vs. $42 \%$ : ATO vs. ATO + BSO), increased cleavage of caspase- 3 and downregulated XIAP (Fig. 6A). Nonetheless, administration of $10 \mathrm{mM}$ NAC 
A

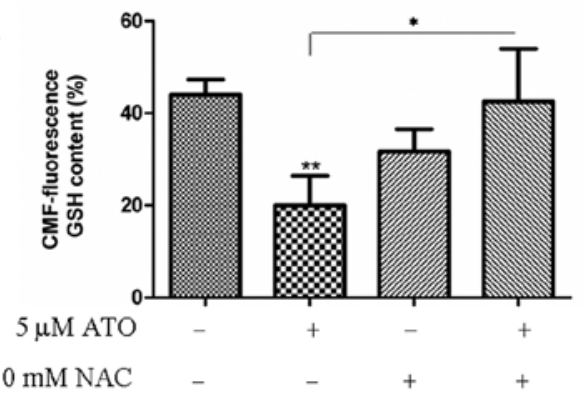

B

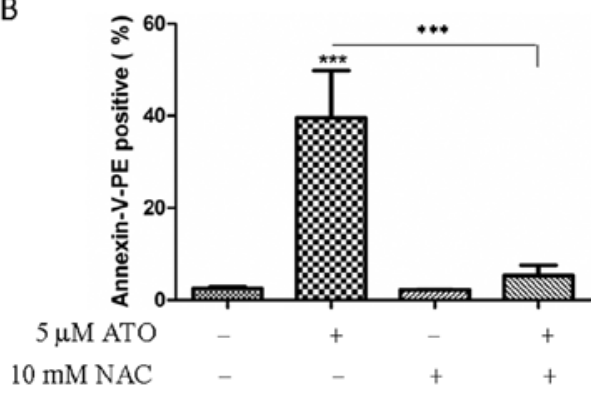

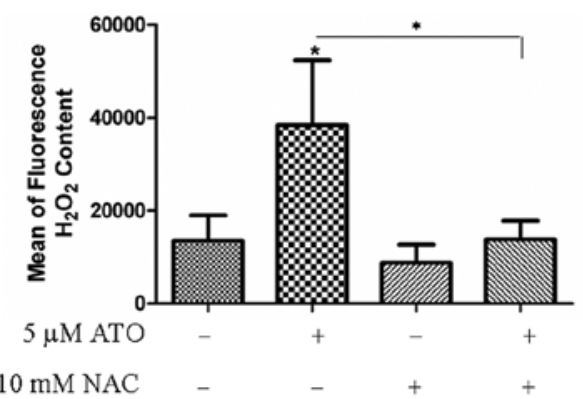

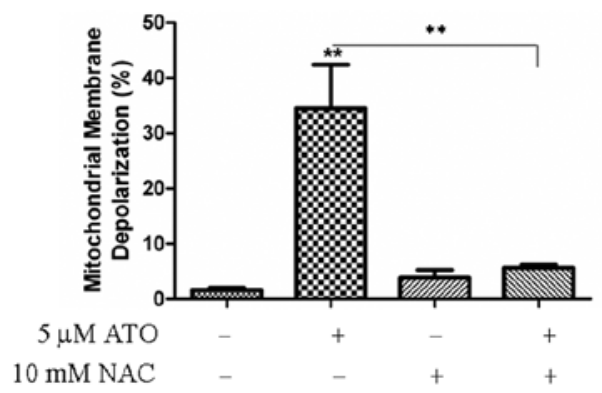

C

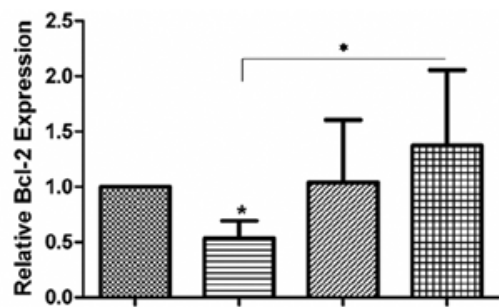

Bcl-2

$\beta$-actin

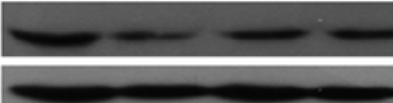

$5 \mu \mathrm{M}$ ATO

10 mM NAC

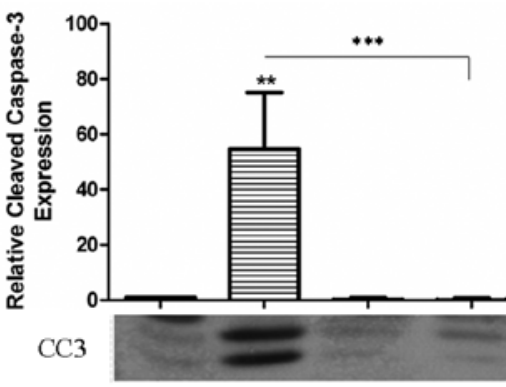

$\beta$-actin

$5 \mu \mathrm{M}$ ATO

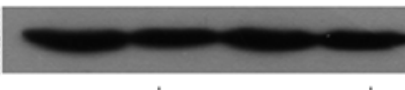

10 mM NAC

$10 \mathrm{mM} \mathrm{NAC}$

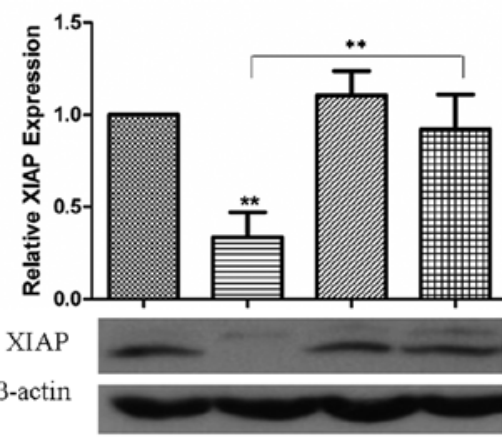

$5 \mu \mathrm{M}$ ATO

10 mM NAC

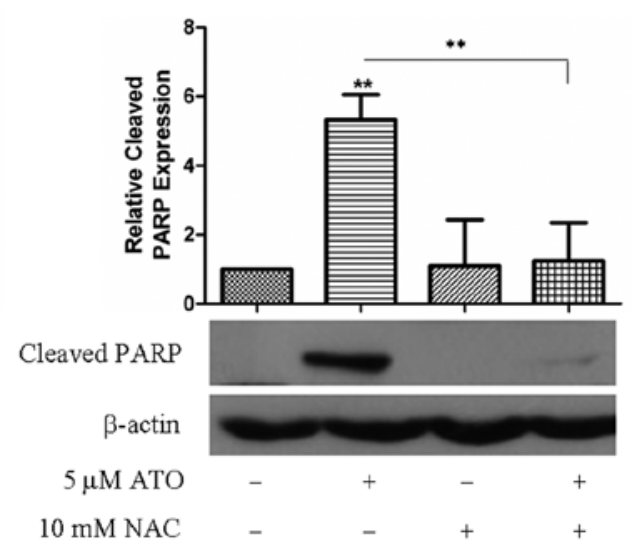

Figure 5. Role of oxidative stress in ATO-mediated apoptosis in $\mathrm{H} 841$ cell line. Addition of NAC (10 mM) to ATO (5 $\mu \mathrm{M})$ resulted in (A) complete reversal of ATO-induced alterations in $\mathrm{GSH}$ and $\mathrm{H}_{2} \mathrm{O}_{2}$ content, (B) protection from mitochondrial membrane depolarization and apoptotic cell death induced by ATO, and (C) normalization of downregulated anti-apoptotic molecules (Bcl-2 and XIAP) and upregulated apoptotic markers (cleaved caspase-3 and cleaved PARP) due to ATO.

only partially rescued the $\mathrm{H} 841$ cells from apoptosis and MMD (Fig. 6A). Interestingly, BSO caused more accumulation of $\mathrm{H}_{2} \mathrm{O}_{2}$ than further depletion of GSH when combined with ATO (Fig. 6B), resulting in increased oxidative DNA damage (8-OHdG-FITC signal) in BSO/ATO group compared with either ATO or BSO alone (Fig. 6C). 

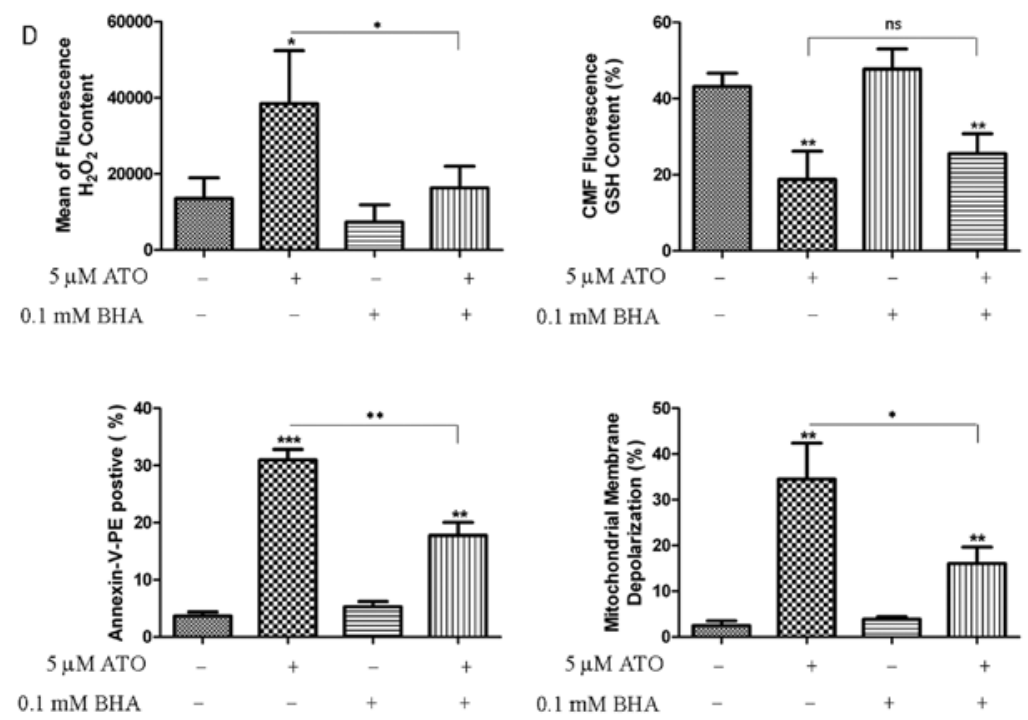

Figure 5. Continued. However, (D) BHA (0.1 mM) could suppress ATO-induced $\mathrm{H}_{2} \mathrm{O}_{2}$ accumulation without restoration of GSH, leading to only partial alleviation of mitochondrial membrane depolarization and apoptosis. Statistical significance $\left({ }^{*} \mathrm{p}<0.05 ;{ }^{* *} \mathrm{p}<0.01\right.$ and ${ }^{* * *} \mathrm{p}<0.001 ;$ ns, not significant) indicates comparison with control.
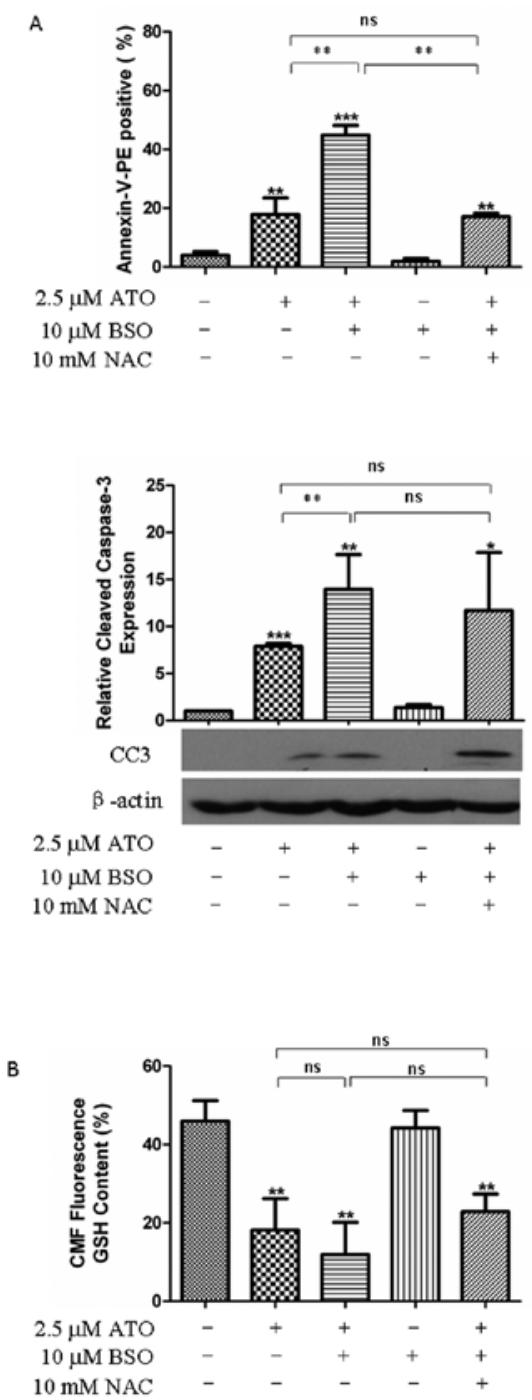
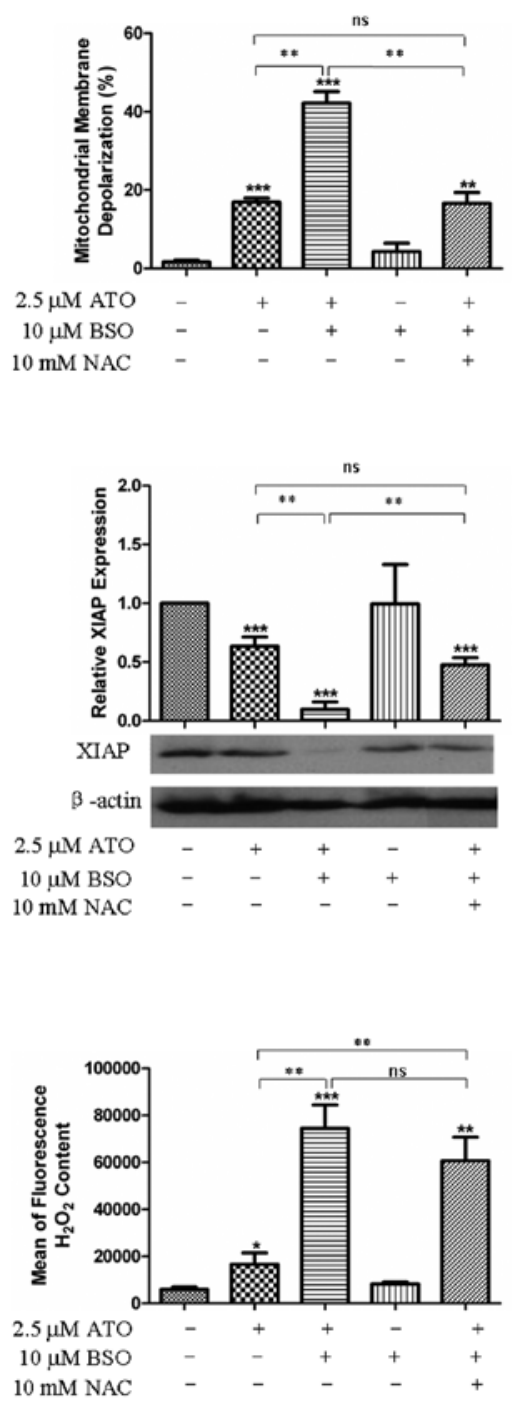

Figure 6. Effect of BSO on cytotoxicity of ATO in $\mathrm{H} 841$ cells. (A) BSO potentiated the mitochondrial membrane depolarization and apoptotic cell death due to ATO, accompanied by increased cleaved caspase- 3 and decreased XIAP, which could only be partially reversed by NAC. (B) $\mathrm{BSO}$ increased $\mathrm{H}_{2} \mathrm{O}_{2}$ dramatically rather than depleting GSH further when combined with ATO, which could not be restored by NAC. Statistical significance $\left({ }^{*} \mathrm{p}<0.05 ;{ }^{* *} \mathrm{p}<0.01\right.$ and ${ }^{* * *} \mathrm{p}<0.001$; ns, not significant) indicates comparison with control. 


\section{C}
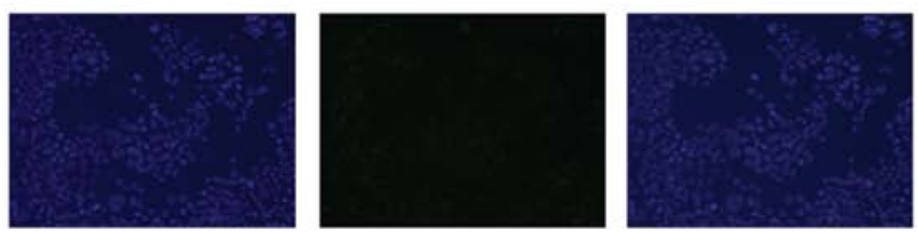

Control
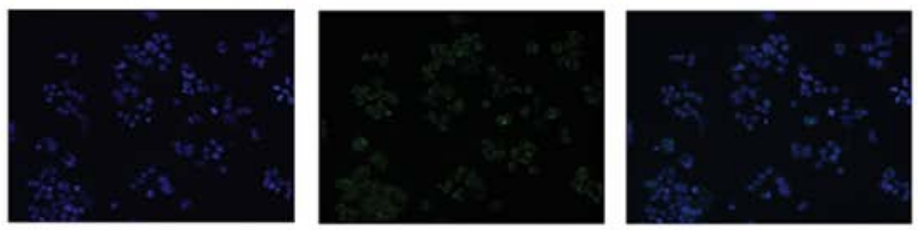

$2.5 \mu \mathrm{M}$ ATO
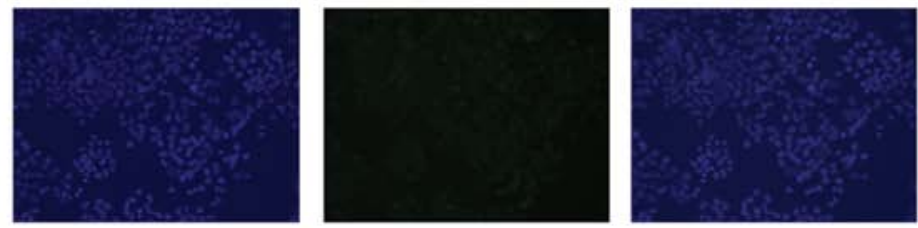

$10 \mu \mathrm{M}$ BSO

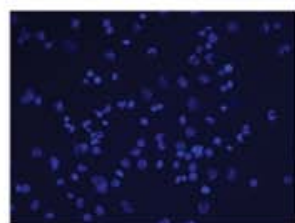

DAPI

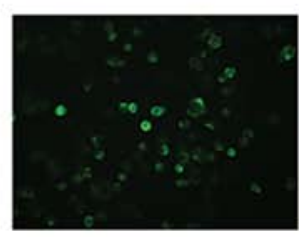

FITC

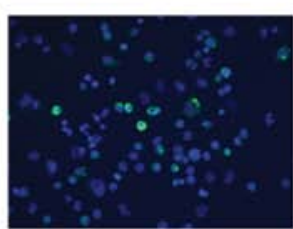

Merged
D

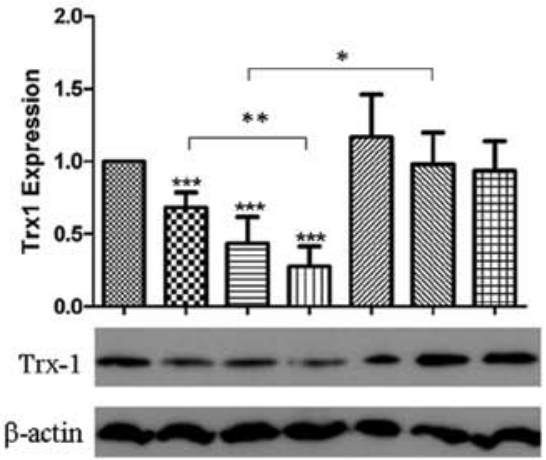

$\begin{array}{llllllll}\mathrm{ATO}(\mu \mathrm{M}) & 0 & 2.5 & 5 & 2.5 & 0 & 5 & 0\end{array}$

$10 \mu \mathrm{MBSO}$ - - -++-

$10 \mathrm{mMNAC} \quad \ldots+\ldots+$

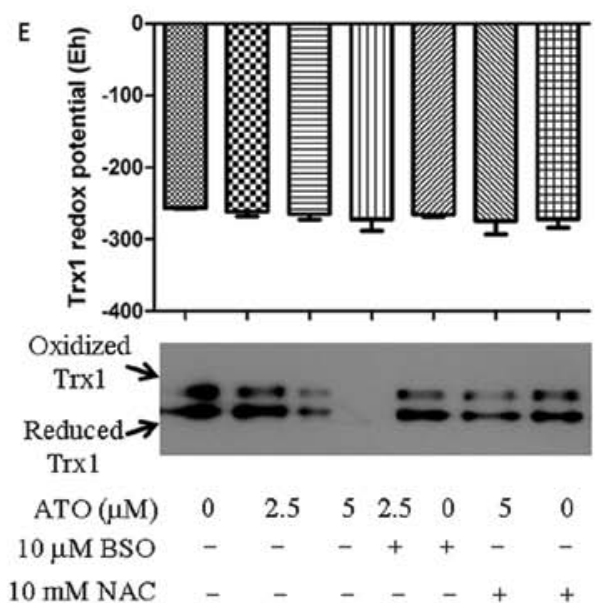

Figure 6. Continued. (C) BSO enhanced oxidative DNA damage when combined with ATO, as indicated by 8-OHdG-FITC staining. (D) ATO reduced Trx1 protein expression, which could be potentiated by BSO and reversed by NAC. (E) Despite reduction of both reduced and oxidized form of Trx1 by ATO (enhanced by addition of BSO), Trx1 redox potential was unaffected. Statistical significance $\left({ }^{*} \mathrm{p}<0.05 ;{ }^{* *} \mathrm{p}<0.01\right.$ and ${ }^{* * * *} \mathrm{p}<0.001 ; \mathrm{ns}$, not significant) indicates comparison with control.

Trx1 is one of the important components of Trx redox system responsible for maintaining redox equilibrium in mammalian cells. ATO reduced total Trx1 protein expression in H841 cells, which could be further downregulated by BSO but was reversed by NAC (Fig. 6D). Based on Trx redox western blot analysis, both oxidized and reduced forms of Trx1 were downregulated by ATO, nevertheless, redox potential (Eh) remained the same in different treatment groups (Fig. 6E).

\section{Discussion}

In the past decade, ATO has been used as a highly effective anticancer therapy in leukemia (particularly APL) with or without all-trans retinoic acid and achieving high rate of complete remission $(2,3)$. Nonetheless, it has been increasingly reported to exert cytotoxic effect in other forms of haematological malignancies and solid cancers such as breast (37), ovarian (38), cervical (39), and lung (20) cancers. The mechanisms and pathways involved are highly diverse and cell type-specific, though knowledge is scarce in SCLC.

In this study, a panel of five SCLC cell lines was tested for the effect of $\mathrm{ATO}$ on cellular proliferation, with $\mathrm{IC}_{50}$ values in clinical achievable concentrations (3).

Caspase-dependent apoptosis is classified into intrinsic (mitochondria-mediated) and extrinsic (death receptor-mediated) pathways (40). Both mechanisms converge to activate the 
apoptotic executioner caspase-3 and -7 , which consequently cleave polyADP-ribose polymerase (PARP) that impairs DNA repair. Classically, cleaved caspase- 3 and cleaved PARP are widely adopted apoptotic markers. In this study, both markers were elevated after ATO treatment in H841 cells, indicating cell death via the caspase-dependent pathway (41).

AIF is one of the main mediators in cell death, which is liberated from mitochondria and translocated to nucleus resulting in DNA damage. It has been suggested that nuclear translocation of AIF accompanied by activation of receptor interacting protein 1 (RIP1) are markers of necroptosis (42). Nonetheless, the binding of AIF with DNA provokes caspaseindependent chromatin condensation and DNA fragmentation (43-46). In our H841 cell line model, apart from triggering MMD accompanied by AIF release and nuclear translocation, ATO treatment also increased RIP1 expression (data not shown). Taken together, cell death initiated by ATO in H841 cells could be mediated through both caspase-dependent apoptosis and AIF-induced apoptosis or necroptosis.

On the other hand, MMD is associated with mitochondrial release of another apoptosis mediator SMAC, in which cytosolic SMAC can inhibit apoptosis inhibitor protein (XIAP) leading to subsequent release of caspases that initiate apoptosis (40). Our finding of SMAC release and XIAP downregulation during treatment with ATO in H841 cells suggests the possibility of caspase-3 activation via SMAC release/XIAP inhibition rather than cytochrome $c$ release/caspase- 9 activation. This is in keeping with previously reported mechanism of caspase-dependent apoptosis via SMAC/XIAP/caspase activation in other cancer cell line models with ATO treatment $(47,48)$.

GSH depletion and $\mathrm{H}_{2} \mathrm{O}_{2}$ accumulation with ATO treatment in $\mathrm{H} 841$ cells detected in this study are in keeping with previous reports $(11,49-52)$. Nonetheless, the type and amount of ROS needed to initiate cell death by ATO are still controversial, which can vary with different cell lines and dose of ATO (53). Indeed, the role of ROS in causing cell death induced by ATO was uncertain in other studies $(54,55)$. Based on our findings in H841 SCLC model, oxidative stress with ATO treatment was due to both $\mathrm{H}_{2} \mathrm{O}_{2}$ production and $\mathrm{GSH}$ depletion, in which NAC (a GSH precursor) (56) could reverse these alterations resulting in restoration of mitochondrial membrane potential. In leukemia cell line U973, intracellular GSH depletion could trigger Bax translocation to mitochondria and provoke membrane permeabilization resulting in apoptosis (57). In H841 cell line, we demonstrated downregulation of Bcl-2 upon ATO treatment, abrogating the protection on mitochondria. The mechanism of ATO-induced Bcl-2 downregulation has not been clearly elucidated. Nonetheless Bcl-2 has manifested an antioxidant-like effect in response to either oxidative stress or GSH depletion $(58,59)$. Reversal of ATO-induced Bcl-2 downregulation with NAC in our experiments has suggested the mechanistic role of oxidative stress and GSH depletion.

BHA is an effective scavenger of free radicals widely used in food industry. It has been shown to be effective in scavenging $\mathrm{H}_{2} \mathrm{O}_{2}$ to rescue cells from the DNA damage (60-63). In our study, adding BHA with ATO in $\mathrm{H} 841$ cells was capable of reducing $\mathrm{H}_{2} \mathrm{O}_{2}$ without effective restoration of $\mathrm{GSH}$ content compared with ATO alone, resulting in partial reversal of cell inhibition and apoptosis induced by ATO. It is possible that depletion of GSH with ATO treatment is not only due to consumption by $\mathrm{H}_{2} \mathrm{O}_{2}$ mediated via glutathione peroxidase (GPx) (64) but also direct consumption by ATO (65). In addition, oxidative DNA damage was more pronounced in ATO treatment with BSO compared with ATO alone, associated with significant GSH depletion due to increased $\mathrm{H}_{2} \mathrm{O}_{2}$ as previously reported $(66,67)$. Taken together, GSH depletion plays a more important role in ATO-induced cell death in SCLC, similar to previous findings in NSCLC (66).

Thioredoxin system was reported to be an important target of ATO in some cancers $(26,68)$. In H841 cell line model, ATO downregulated both reduced and oxidative form of Trx 1 without affecting redox status. This is discrepant from previous report, which indicated that ATO could inhibit thioredoxin reductase and consequently decrease the reduced form of Trx1 (68). Although the activity or expression of thioredoxin reductase has not been measured, our findings suggest that ATO targets the total Trx1 rather than just the reduced form in $\mathrm{H} 841$ cells.

MAPKs are potential ROS response factors, nonetheless, p-JNK and p-p38 were not involved in ATO-induced cell death in our H841 cell line model (data not shown), which is different from other cancer models (69-71). Although upregulated p-Erk1/2 was detected after ATO treatment in H841 cells, specific Erk inhibitor PD98059 failed to revert the effects induced by ATO on MMD and cell death. It suggests that $\mathrm{p}$-Erk1/2 is not an effective mediator leading to cell death induced by ATO in SCLC, which may serve in other biological actions $(72,73)$.

In conclusion, the mechanisms of cell death induced by ATO in SCLC are mainly dependent on altered redox homeostasis that comprises GSH depletion, $\mathrm{H}_{2} \mathrm{O}_{2}$ accumulation and mitochondrial depolarization. Both caspase-dependent pathway mediated via Bcl-2/SMAC/XIAP/Caspase-3 and caspase-independent pathway mediated via AIF would take part in causing apoptosis and necroptosis in SCLC.

\section{References}

1. Lally BE, Urbanic JJ, Blackstock AW, Miller AA and Perry MC: Small cell lung cancer: have we made any progress over the last 25 years? Oncologist 12: 1096-1104, 2007.

2. Shen ZX, Chen GQ, Ni JH, et al: Use of arsenic trioxide $\left(\mathrm{As}_{2} \mathrm{O}_{3}\right)$ in the treatment of acute promyelocytic leukemia (APL): II. Clinical efficacy and pharmacokinetics in relapsed patients. Blood 89: 3354-3360, 1997.

3. Chen GQ, Shi XG, Tang W, et al: Use of arsenic trioxide $\left(\mathrm{As}_{2} \mathrm{O}_{3}\right)$ in the treatment of acute promyelocytic leukemia (APL): $\mathrm{I} . \mathrm{As}_{2} \mathrm{O}_{3}$ exerts dose-dependent dual effects on APL cells. Blood 89: 3345-3353, 1997.

4. Yoda A, Toyoshima K, Watanabe Y, et al: Arsenic trioxide augments Chk2/p53-mediated apoptosis by inhibiting oncogenic Wip1 phosphatase. J Biol Chem 283: 18969-18979, 2008.

5. Li Y, Qu X, Qu J, et al: Arsenic trioxide induces apoptosis and G2/M phase arrest by inducing Cbl to inhibit PI3K/Akt signaling and thereby regulate p53 activation. Cancer Lett 284: 208-215, 2009.

6. Scholz C, Richter A, Lehmann M, Schulze-Osthoff K, Dorken B and Daniel PT: Arsenic trioxide induces regulated, death receptorindependent cell death through a Bcl-2-controlled pathway. Oncogene 24: 7031-7042, 2005.

7. Chen GQ, Zhu J, Shi XG, et al: In vitro studies on cellular and molecular mechanisms of arsenic trioxide $\left(\mathrm{As}_{2} \mathrm{O}_{3}\right)$ in the treatment of acute promyelocytic leukemia: $\mathrm{As}_{2} \mathrm{O}_{3}$ induces NB4 cell apoptosis with downregulation of Bcl-2 expression and modulation of PML-RAR alpha/PML proteins. Blood 88: 1052-1061, 1996 
8. Kang YH, Yi MJ, Kim MJ, et al: Caspase-independent cell death by arsenic trioxide in human cervical cancer cells: reactive oxygen species-mediated poly(ADP-ribose) polymerase-1 activation signals apoptosis-inducing factor release from mitochondria Cancer Res 64: 8960-8967, 2004.

9. Shen ZY, Shen J, Cai WJ, Hong C and Zheng MH: The alteration of mitochondria is an early event of arsenic trioxide induced apoptosis in esophageal carcinoma cells. Int J Mol Med 5: $155-158,2000$

10. Dalton WS: Targeting the mitochondria: an exciting new approach to myeloma therapy. Commentary re: N.J. Bahlis et al: Feasibility and correlates of arsenic trioxide combined with ascorbic acid-mediated depletion of intracellular glutathione for the treatment of relapsed/refractory multiple myeloma. in Clin Cancer Res 8: 3658-3668, 2002. Clin Cancer Res 8: 3643-3645, 2002.

11. Bhalla S, Gordon LI, David K, et al: Glutathione depletion enhances arsenic trioxide-induced apoptosis in lymphoma cells through mitochondrial-independent mechanisms. Br J Haematol 150: 365-369, 2010

12. Davison K, Cote S, Mader S and Miller WH: Glutathione depletion overcomes resistance to arsenic trioxide in arsenicresistant cell lines. Leukemia 17: 931-940, 2003.

13. Walker AM, Stevens JJ, Ndebele K and Tchounwou PB: Arsenic trioxide modulates DNA synthesis and apoptosis in lung carcinoma cells. Int J Environ Res Public Health 7: 1996-2007, 2010.

14. Qu GP, Xiu QY, Li B, Liu YA and Zhang LZ: Arsenic trioxide inhibits the growth of human lung cancer cell lines via cell cycle arrest and induction of apoptosis at both normoxia and hypoxia. Toxicol Ind Health 25: 505-515, 2009.

15. Han YH, Kim SZ, Kim SH and Park WH: Induction of apoptosis in arsenic trioxide-treated lung cancer A549 cells by buthionine sulfoximine. Mol Cells 26: 158-164, 2008.

16. Lam SK, Li YY, Zheng CY, Leung LL and Ho JC: E2F1 downregulation by arsenic trioxide in lung adenocarcinoma. Int $\mathrm{J}$ Oncol 45: 2033-2043, 2014.

17. Lam SK, Mak JC, Zheng CY, Li YY, Kwong YL and Ho JC: Downregulation of thymidylate synthase with arsenic trioxide in lung adenocarcinoma. Int J Oncol 44: 2093-2102, 2014.

18. Lam SK, Li YY, Zheng CY and Ho JC: Downregulation of thymidylate synthase and E2F1 by arsenic trioxide in mesothelioma. Int J Oncol 46: 113-122, 2015.

19. Li H, Zhu X, Zhang Y, Xiang J and Chen H: Arsenic trioxide exerts synergistic effects with cisplatin on non-small cell lung cancer cells via apoptosis induction. J Exp Clin Cancer Res 28: $110,2009$.

20. Chien CW, Yao JH, Chang SY, Lee PC and Lee TC: Enhanced suppression of tumor growth by concomitant treatment of human lung cancer cells with suberoylanilide hydroxamic acid and arsenic trioxide. Toxicol Appl Pharmacol 257: 59-66, 2011.

21. Park JH, Kim EJ, Jang HY, et al: Combination treatment with arsenic trioxide and sulindac enhances apoptotic cell death in lung cancer cells via activation of oxidative stress and mitogenactivated protein kinases. Oncol Rep 20: 379-384, 2008.

22. Pettersson HM, Pietras A, Munksgaard Persson M, et al: Arsenic trioxide is highly cytotoxic to small cell lung carcinoma cells. Mol Cancer Ther 8: 160-170, 2009.

23. Miller WH Jr, Schipper HM, Lee JS, Singer J and Waxman S Mechanisms of action of arsenic trioxide. Cancer Res 62 3893-3903, 2002.

24. Carney DA: Arsenic trioxide mechanisms of action - looking beyond acute promyelocytic leukemia. Leuk Lymphoma 49: $1846-1851,2008$

25. Chouchane $S$ and Snow ET: In vitro effect of arsenical compounds on glutathione-related enzymes. Chem Res Toxicol 14: 517-522, 2001.

26. Lu J, Chew EH and Holmgren A: Targeting thioredoxin reductase is a basis for cancer therapy by arsenic trioxide. Proc Natl Acad Sci USA 104: 12288-12293, 2007.

27. Kim HJ, Chae HZ, Kim YJ, et al: Preferential elevation of Prx I and Trx expression in lung cancer cells following hypoxia and in human lung cancer tissues. Cell Biol Toxicol 19: 285-298, 2003.

28. Hedley D, Pintilie M, Woo J, et al: Up-regulation of the redox mediators thioredoxin and apurinic/apyrimidinic excision (APE)/Ref-1 in hypoxic microregions of invasive cervical carcinomas, mapped using multispectral, wide-field fluorescence image analysis. Am J Pathol 164: 557-565, 2004.

29. Choi JH, Kim TN, Kim S, et al: Overexpression of mitochondrial thioredoxin reductase and peroxiredoxin III in hepatocellular carcinomas. Anticancer Res 22: 3331-3335, 2002.
30. Powis G, Mustacich D and Coon A: The role of the redox protein thioredoxin in cell growth and cancer. Free Radic Biol Med 29: 312-322, 2000

31. Tonissen KF and Di Trapani G: Thioredoxin system inhibitors as mediators of apoptosis for cancer therapy. Mol Nutr Food Res 53: 87-103, 2009.

32. Zheng CY, Lam SK, Li YY, Fong BM, Mak JC and Ho JC: Combination of arsenic trioxide and chemotherapy in small cell lung cancer. Lung Cancer 82: 222-230, 2013.

33. Tauskela JS, Hewitt K, Kang LP, et al: Evaluation of glutathionesensitive fluorescent dyes in cortical culture. Glia 30: 329-341, 2000.

34. Sordet O, Liao Z, Liu H, et al: Topoisomerase I-DNA complexes contribute to arsenic trioxide-induced apoptosis. J Biol Chem 279: 33968-33975, 2004

35. Watson WH, Pohl J, Montfort WR, et al: Redox potential of human thioredoxin 1 and identification of a second dithiol/ disulfide motif. J Biol Chem 278: 33408-33415, 2003.

36. Go YM and Jones DP: Thioredoxin redox western analysis. Curr Protoc Toxicol: Chapter 17: Unit17.12. doi: 10.1002/0471140856. tx1712s41. 2009

37. Sun RC, Board PG and Blackburn AC: Targeting metabolism with arsenic trioxide and dichloroacetate in breast cancer cells. Mol Cancer 10: 142, 2011

38. Askar N, Cirpan T, Toprak E, et al: Arsenic trioxide exposure to ovarian carcinoma cells leads to decreased level of topoisomerase II and cytotoxicity. Int J Gynecol Cancer 16: 1552-1556, 2006

39. Wen X, Li D, Zhang Y, Liu S, Ghali L and Iles RK: Arsenic trioxide induces cervical cancer apoptosis, but specifically targets human papillomavirus-infected cell populations. Anticancer Drugs 23: 280-287, 2012.

40. Fulda S and Debatin KM: Extrinsic versus intrinsic apoptosis pathways in anticancer chemotherapy. Oncogene 25: 4798-4811, 2006.

41. Lam HK, Li K, Chik KW, et al: Arsenic trioxide mediates intrinsic and extrinsic pathways of apoptosis and cell cycle arrest in acute megakaryocytic leukemia. Int J Oncol 27: 537-545, 2005.

42. Delavallee L, Cabon L, Galan-Malo P, Lorenzo HK and Susin SA: AIF-mediated caspase-independent necroptosis: a new chance for targeted therapeutics. IUBMB Life 63: 221-232, 2011.

43. Cande C, Cecconi F, Dessen P and Kroemer G: Apoptosisinducing factor (AIF): key to the conserved caspase-independent pathways of cell death? J Cell Sci 115: 4727-4734, 2002

44. Susin SA, Lorenzo HK, Zamzami N, et al: Molecular characterization of mitochondrial apoptosis-inducing factor. Nature 397: 441-446, 1999

45. LorenzoHK and Susin SA: Therapeutic potential of AIF-mediated caspase-independent programmed cell death. Drug Resist Updat 10: 235-255, 2007

46. Ye H, Cande C, Stephanou NC, et al: DNA binding is required for the apoptogenic action of apoptosis inducing factor. Nat Struct Biol 9: 680-684, 2002.

47. Choi YJ, Park JW, Suh SI, et al: Arsenic trioxide-induced apoptosis in U937 cells involve generation of reactive oxygen species and inhibition of Akt. Int J Oncol 21: 603-610, 2002.

48. Calvino E, Estan MC, Simon GP, et al: Increased apoptotic efficacy of lonidamine plus arsenic trioxide combination in human leukemia cells. Reactive oxygen species generation and defensive protein kinase (MEK/ERK, Akt/mTOR) modulation. Biochem Pharmacol 82: 1619-1629, 2011.

49. Xiao G, Tang X, Yao C and Wang C: Potentiation of arsenic trioxide-induced apoptosis by 8-bromo-7-methoxychrysin in human leukemia cells involves depletion of intracellular reduced glutathione. Acta Biochim Biophys Sin 43: 712-721, 2011.

50. Konig H, Hartel N, Schultheis B, et al: Enhanced Bcr-Abl-specific antileukemic activity of arsenic trioxide (Trisenox) through glutathione-depletion in imatinib-resistant cells. Haematologica 92: 838-841, 2007.

51. Ramos AM, Fernandez C, Amran D, Sancho P, de Blas E and Aller P: Pharmacologic inhibitors of PI3K/Akt potentiate the apoptotic action of the antileukemic drug arsenic trioxide via glutathione depletion and increased peroxide accumulation in myeloid leukemia cells. Blood 105: 4013-4020, 2005.

52. Hu XM, Hirano T and Oka K: Arsenic trioxide induces apoptosis in cells of MOLT-4 and its daunorubicin-resistant cell line via depletion of intracellular glutathione, disruption of mitochondrial membrane potential and activation of caspase-3. Cancer Chemother Pharmacol 52: 47-58, 2003. 
53. Han YH, Moon HJ, You BR, Kim SZ, Kim SH and Park WH: Effects of arsenic trioxide on cell death, reactive oxygen species and glutathione levels in different cell types. Int J Mol Med 25: 121-128, 2010.

54. Yi J, Yang J, He R, et al: Emodin enhances arsenic trioxideinduced apoptosis via generation of reactive oxygen species and inhibition of survival signaling. Cancer Res 64: 108-116, 2004.

55. Morales AA, Gutman D, Cejas PJ, Lee KP and Boise LH: Reactive oxygen species are not required for an arsenic trioxideinduced antioxidant response or apoptosis. J Biol Chem 284 12886-12895, 2009.

56. Sun SY: N-acetylcysteine, reactive oxygen species and beyond. Cancer Biol Ther 9: 109-110, 2010.

57. Guha P, Dey A, Sen R, Chatterjee M, Chattopadhyay S and Bandyopadhyay SK: Intracellular GSH depletion triggered mitochondrial Bax translocation to accomplish resveratrol-induced apoptosis in the U937 cell line. J Pharmacol Exp Ther 336 : 206-214, 2011

58. Voehringer DW and Meyn RE: Redox aspects of Bcl-2 function Antioxid Redox Signal 2: 537-550, 2000.

59. Hochman A, Sternin H, Gorodin S, et al: Enhanced oxidative stress and altered antioxidants in brains of Bcl-2-deficient mice. J Neurochem 71: 741-748, 1998.

60. Rajesh K, Vedamurthy J, Prakash D, Thammanna Gowda SS, Satish BP and Dinesha R: Antioxidant activity of spathodea campanulata in prevention of TBOOH and $\mathrm{H}_{2} \mathrm{O}_{2}$ induced DNA damage. Int J Curr Pharmaceut Res 3: 3, 2011.

61. Keser S, Celik S, Turkoglu S, Yilmaz Ö and Turkoglu I: Hydrogen peroxide radical scavenging and total antioxidant activity of Hawthorn. Chem J 2: 4, 2012.

62. Cherouny PH, Ghodgaonkar RB, Gurtner GH and Dubin NH: The effect of the antioxidant, butylated hydroxy anisole, on peroxide-induced and spontaneous activity of the uterus from the pregnant rat. Biol Reprod 41: 98-103, 1989.

63. Gulcin I, Alici HA and Cesur M: Determination of in vitro antioxidant and radical scavenging activities of propofol. Chem Pharm Bull 53: 281-285, 2005.
64. Lushchak VI: Glutathione homeostasis and functions: potential targets for medical interventions. J Amino Acids: 736837, 2012.

65. Patrick L: Toxic metals and antioxidants: Part II. The role of antioxidants in arsenic and cadmium toxicity. Altern Med Rev 8: 106-128, 2003.

66. Han YH, Kim SH, Kim SZ and Park WH: Apoptosis in arsenic trioxide-treated Calu- 6 lung cells is correlated with the depletion of GSH levels rather than the changes of ROS levels. J Cell Biochem 104: 862-878, 2008.

67. Reliene R and Schiestl RH: Glutathione depletion by buthionine sulfoximine induces DNA deletions in mice. Carcinogenesis 27: 240-244, 2006.

68. Tian C, Gao P, Zheng Y, et al: Redox status of thioredoxin-1 (TRX1) determines the sensitivity of human liver carcinoma cells (HepG2) to arsenic trioxide-induced cell death. Cell Res 18: 458-471, 2008.

69. Kang YH and Lee SJ: The role of p38 MAPK and JNK in arsenic trioxide-induced mitochondrial cell death in human cervical cancer cells. J Cell Physiol 217: 23-33, 2008.

70. Han YH, Moon HJ, You BR, Kim SZ, Kim SH and Park WH The effect of MAPK inhibitors on arsenic trioxide-treated Calu-6 lung cells in relation to cell death, ROS and GSH levels. Anticancer Res 29: 3837-3844, 2009.

71. Zhang S, Guo W, Ren TT, Lu XC, Tang GQ and Zhao FL: Arsenic trioxide inhibits Ewing's sarcoma cell invasiveness by targeting p38(MAPK) and c-Jun N-terminal kinase. Anticancer Drugs 23: 108-118, 2012.

72. Chiu HW, Ho SY, Guo HR and Wang YJ: Combination treatment with arsenic trioxide and irradiation enhances autophagic effects in U118-MG cells through increased mitotic arrest and regulation of PI3K/Akt and ERK1/2 signaling pathways. Autophagy 5: 472-483, 2009.

73. Ellington AA, Berhow MA and Singletary KW: Inhibition of Akt signaling and enhanced ERK1/2 activity are involved in induction of macroautophagy by triterpenoid B-group soyasaponins in colon cancer cells. Carcinogenesis 27: 298-306, 2006. 